EPJ Web of Conferences 78, 01007 (2014)

DOI: $10.1051 /$ epjconf/20147801007

CC Owned by the authors, published by EDP Sciences, 2014

\title{
Eugene Wigner, Pupil of a legendary School
}

Dr. László Kovács

West-Hungarian University, Szombathely

\section{Introduction}

In the foreword to one of his most important works Eugene P. Wigner, (Hungarian Jenő Wigner) wrote:

"Most readers of this work know that I, the third author, am of Hungarian birth. Much water has flown down the Danube since I last bathed in it. Time, however, has not washed away the gratitude I feel toward my birthplace. I have not forgotten that it was my cradle and sustained me in my initial studies. Rarely do I neglect such opportunities to express gratitude to my teachers and the Budapest Lutheran Gimnasium. Never will I forget my former teachers, among them teacher of mathematics László Rácz, a genuine pedagogue and warmhearted man, who first awoke in me a love for his subject."

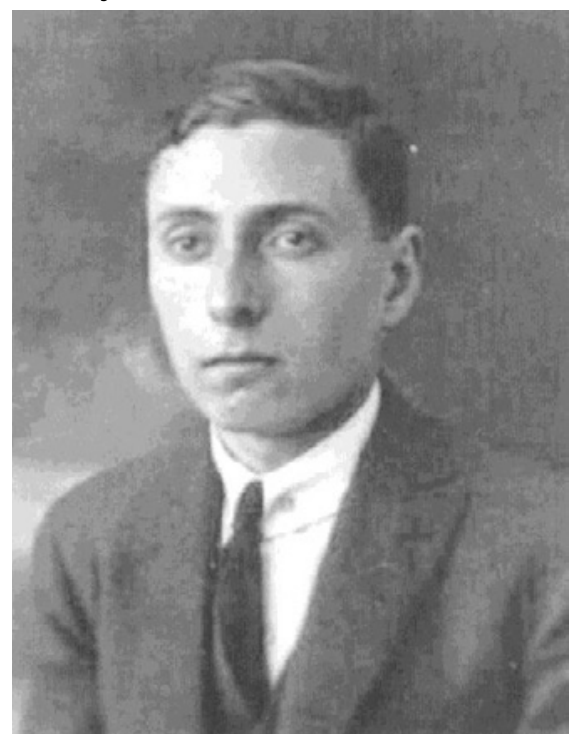

Eugene Wigner

(L. Eisenbud - G.T. Garvey - E.P.Wigner: Az atommag szerkezete, Akadémiai Kiadó, Budapest, 1969. /based on: L.E. - G.T.G. - E.P.W.: General Principle of Nuclear Structure, in Handbook of Physics, Ed. by E.V.Condon, H.Odishaw, 2. Ed. Mc Graw Hill Book Co. New York, 1967/) 
The gifted teacher employs humanity and enthusiasm to kindle a love of his subject and he leaves an everlasting impression on his students by drawing upon his deep knowledge and broad range of pedagogical skills to teach his subject.

"Naturally, we learned physics from Sándor Mikola," Wigner recalled. "I am proud to say that after two years of study (under his guidance at the secondary school), the physics courses at the Budapest University of Technical Sciences (Müegyetem) and the Berlin Technische Hochschule seemed to be almost mere repetition."

(F. S. Wagner: Eugen P. Wigner: An Architect of the Atomic Age, Rákóczi Foundation, Toronto, Clevland, 1981).

\section{The Budapest Lutheran Gymnasium}

People are looking for the secret of the Budapest Lutheran („Fasori”) Gymnasium, which compares well with the achievements of the Bronx High School of Science in the United States, New York. Leon Lederman, the Nobelprize winner found a motive. "Historians have noted how Baron Eötvös's educational efforts led to an explosion of genius - such luminaries as the physicist Edward Teller, Eugene Wigner, Leo Szilard and the mathematician John von Neumann all came out Budapest during the Eötvös era."

(L. Ledermann-Dick Teresi: The God Particle, Houghton Mifflin Company, Boston, New York, 1993.)

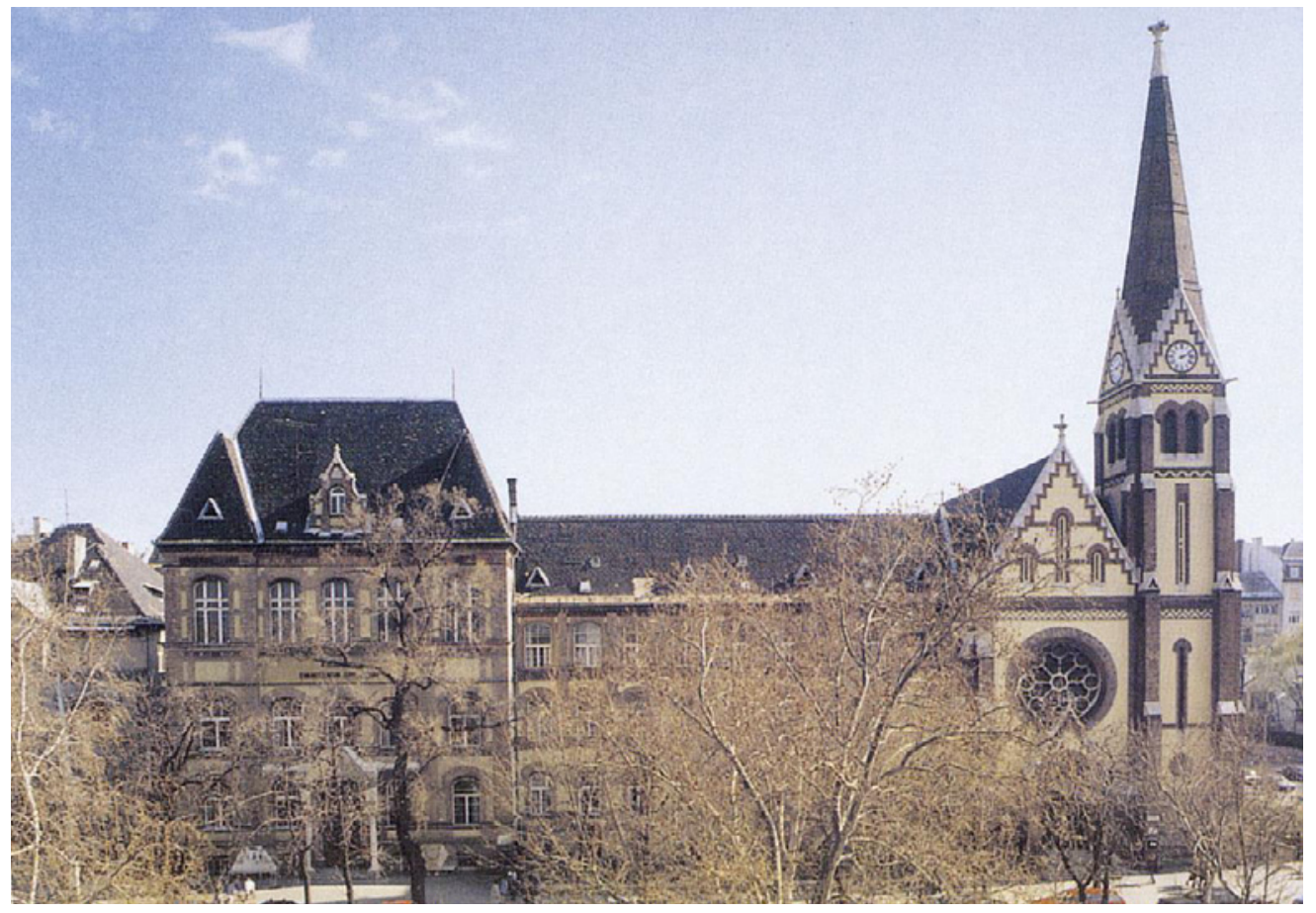

Budapeti Lutheran ("Fasori") Gymnasium

Baron Loránd Eötvös was the greatest Hungarian physicist, His name is commemorated in the Eötvös Law, in the Eötvös gravitational torsion balance and in the Eötvös-effect. 
The Lutheran Gymnasium in 1863 occupied new premises on Sütő Street, where it remained until 1904, the year in which it moved to its present location on the "Fasor"(Avenue). The teachers of the Lutheran School regularly engaged in scholarly research; between 1873 and 1924 nine and after that until now nine more Lutheran School teachers were named members of the Hungarian Academy of Sciences, and among the teachers of Jenő Wigner were 9 ones who earned doctordegree.

The Lutheran School was generously equipped. The bequest of Bogumér Szentiványi enabled the school library to increase its holdings to 8000 volumes in 1867, and a further 2000 were added by 1885. In 1900 the school subscribed to 27 different periodicals, and that number increased to 29 in 1914. In the new premises of the school on Fasor, the natural history laboratory included 2600 specimens of minerals identified and labelled by András Kubacska. By the beginning of the twentieth century, the school maintained large collections of moths and butterflies (2357 specimens), photographic slides (1000 items) and coins (2515 items).

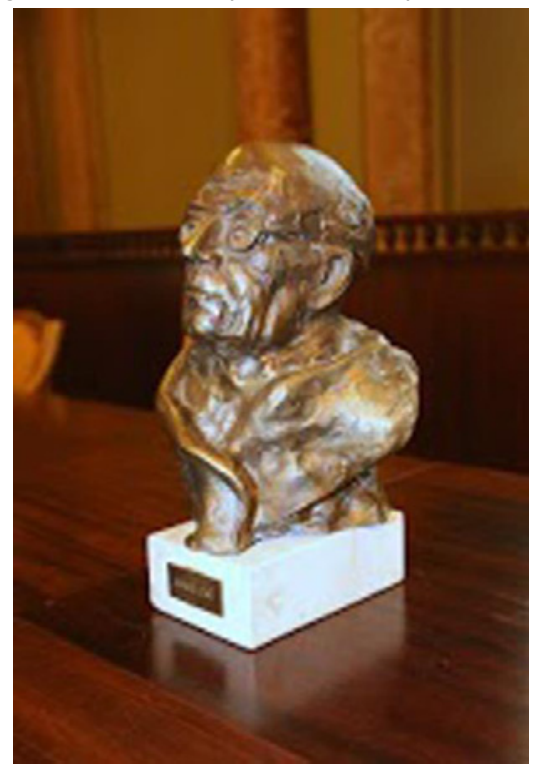

Bronz bust of Jenő Wigner

(Pál Farkas 1995)

Discipline was highly strict and consistent at the Lutheran School. The teachers worked conscientiously to develop in their charges two important human properties: "moral character" and independence of thought.

In 1862 teachers of the Lutheran School founded the Hungarian Autodidactic Society, officially known as the János Arany Autodidactic Society until the school's nationalisation in 1952. Although the organisation's primary mission was the cultivation of the Hungarian language and literature, it welcomed those with an interest in the natural sciences to deliver lectures and take part in its competitions. Those whose work the members greeted with praise could record the fact in the "Book of Merit", where we can find two entries devoted to the successes of Jenő Wigner. 
8 February 1919:

"At the meeting of the János Arany Society of 8 February 1919 Jenö Wigner's study devoted to the theory of relativity won a notice in the Book of Merit. (The absence of objectiv aberratio. The "inert ether." What does it mean to say that a body "stands." Definitions of the special and general theories of relativity. Lorentz transformations. The reduction of distances and its basis for the impossibility of rigid bodies. The latter serving as a consequence for the general theory of relativity. The force of gravity. Gauss coordinates. Comparison of classical mechanics and the special and general theories of relativity).

Jenö Wigner

Pupil of the VII Form"

In the section dated 28 November 1919, the Book of Merit includes an entry devoted to Pál Wámoscher's paper entitled "Jókai", which precedes the following entry in Wigner's hand:

"At the same meeting Jenö Wigner earned an entry in the Book of Merit for his critique of the forementioned paper."

The parents of the pupils, manufacturers, prominent public figures, and former pupils contributed substantial sums of money to the school and created endowments which enabled the faculty to improve the school and award the most accomplished pupils. In the second half of the nineteenth century, the first such award was established by Károly Döbröntei, secretary of the Hungarian Academy of Sciences - a gold piece to be awarded the pupil who wrote the best essay in Hungarian and his teacher. The 18-crown prize in memory of Dezső Lamm, who died in 1898, was won by Jenő Wigner in the 1916-17 school year when he was in the fifth form. In the following school year, János Neumann was recognised as "the best mathematician in the fifth form" with a prize of 10 crowns. On 3 July 1920, upon recommendation of the "Graduating Examination Committee", the faculty awarded the Antal Weiss Mathematics Prize in the amount of 20 crowns to Jenő Wigner. The school's "Annual Report", The Bulletin of the Lutheran Gymnasium of 1916-17 notes that the parents of Jenő Wigner were among the financial supporters of such awards.

\section{László Rácz}

(9 April 1863 Sopron - 30 September 1930 Budapest)

Rátz's most noteworthy scholarly endeavors included his leading role in the implementation of reforms in secondary-school mathematics education (1905-1914) and his editorship (as successor to Dániel Arany) of the Középiskolai Matematikai Lapok (Journal of Secondary-School Mathematics) from 1896 to 1914. Certain of those mathematics problems and their solutions which had appeared in that journal were thematically organised and published separately by Rátz under the title Matematikai Gyakorlókönyv 1-2 (Mathematics Practice Book 1-2), which appeared in two installments in 1904 and 1905.

"My favorite passtime as now to solve problems from the Rátz's Mathematics Practice Books" - Wigner recalled in a television interview in 1972. 
Rátz and his collegue Sándor Mikola stressed the importance of mental calculation and the practice of estimating. From their set of new materials and techniques they drew, by way of example, those sections devoted to the teaching of infinitesimal calculus and presented them in a number of publications: Rátz-Mikola, "Az infinitezimális számítás elemei a középiskolában" (Infinitesimal calculus in the secondary school), an article which appeared in the 1910 Annual Report of the Lutheran Gymnasium; in a book bearing the same title and appearing in the same year; and in a more sizeable volume entitled Functions and the elements of infinesimal calculus [A függvények és az infinitezimális számítások elemei], published by Franklin Publishers in 1914.

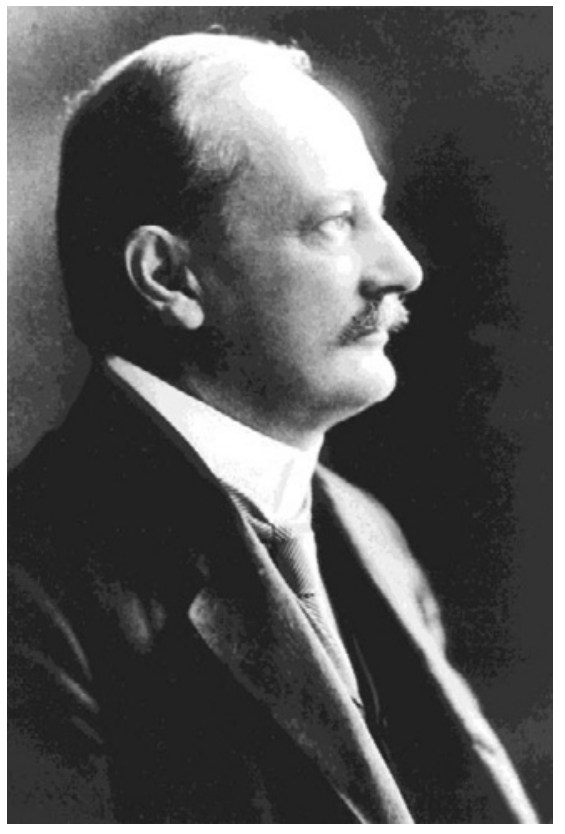

László Rátz

As executive advisor to the National Public Education Council, Rátz helped to prepare the mathematics curriculum of 1924 and instructions for its implementation. On 18 November 1930, Sándor Mikola, at that time director of the Lutheran Gymnasium, announced at a meeting of the faculty that the Lutheran Gymnasium Alumni Association "had initiated a large-scale campaign to immortalise the memory of László Rátz". (Jenő Wigner was an active member of the Alumni Association.) In the year following his death, Rátz was commemorated at the dedication of a large marble plaque bearing his likeness in relief. The work of sculptor Elek Lux, it was hung in the school's stairwell. (László Kovács: Budapest: A Random Walk in Science and Culture, The Physical Tourist, A Science Guide for the Traveler, J. S. Rigden, R. H. Stuewer eds., Birkhausen, Basel, Boston, Berlin, 2009. p175-213) At the same time the Alumni Association made bronze László Rátz Medals with the same portrait of Rátz wich appears in the marble plaque. One can see a copy of the Rátz Medal at the Hungarian National Gallery. (The copy of the medal was displaced during this lecture as part of a small exhibition at the main ceremonial hall of the Hungarian 
Academy of Sciences among the book László Kovács: Eugene P. Wigner and his Hungarian Teachers, Studia Physica Savariensia IX. Szombathely/Hungary, 2002, the small bronze bust of Jenő Wigner made by sculptor Pál Farkas, 1995. /this Wigner bust belangs to the Physics Library housing in Science Faculty of Eötvös University/, and a small study head of Eötvös by sculptor Csaba Barták owing to László Kovács.)

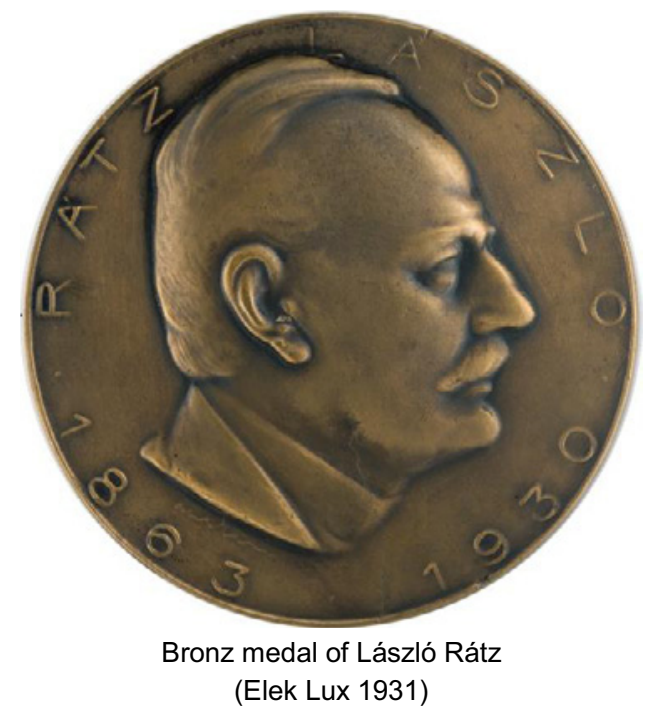

In 1939, Aladar Münnich donated a silver chalice to the Lutheran Gymnasium Alumni Association with the goal of honoring Rátz's memory at an annual László Rátz Memorial Assembly.

\section{Sándor Mikola}

He was born 16 April 1871 in Péterhegy (also known as Gornij Petrovci), an ethnic (vendish) Slovenian village which, at that time, was part of the Hungarian county of Vas and is now a part of Slovenia. He died on 1 October 1945 in Nagykanizsa, where his modest grave can be found in the public cemetery.

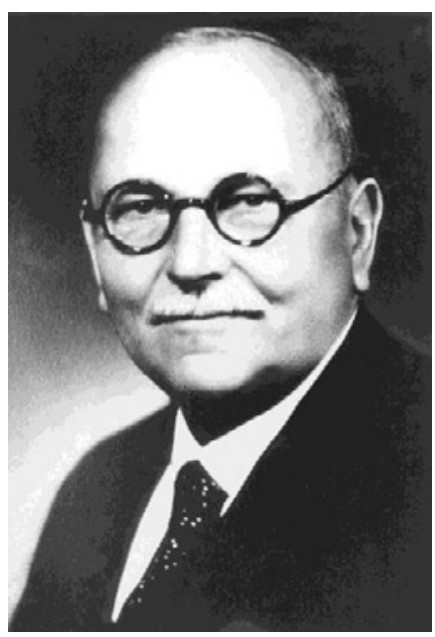

Sándor Mikola 
On 8 May 1921 Mikola was elected a corresponding member of the Hungarian Academy of Sciences in recognition of his experimental research on the electrical behavior of insulating materials. In the course of such work, he experimentally established materials remaining electrical charge for a long time, the so called electrets, independently from the japan Eguchi. The school's physics laboratory was the site of Mikola's important experimental research in electricity which, as noted above, earned him election as a corresponding member of the Hungarian Academy of Sciences in 1921. Rare indeed in the history of Hungarian science are figures like Mikola, who, elected to the Hungarian Academy of Sciences while employed as a secondary school teacher of physics, have remained in that post thereafter.

Mikola's publications in the field of epistemology e. g. Intellectual World of Physics (1933 [A fizika gondolatvilága]) earned him election as an ordinary member of the Hungarian Academy of Sciences on 15 May 1942.

Mikola placed great emphasis on the proper formulation of ideas, and he was a pioneer of the experimental approach to the teaching of physics.

The secret of Mikola's power as a scholar and an educator was his deep humanity. His humanism and balanced temperament sprang from two sources: a deep love of nature and a thorough acquaintance with classical culture. His pedagogical views are relevant in our own day owing to both their deeply humanist pedigree and their role in the development of a new style of physics teaching, which at that time was the best in the world.

\section{Symmetry properties and invariance at Jenö Wigner and Ányos Jedlik}

In his groundbreaking work of 1931, Gruppentheorie und ihre Anwendung auf die Quantenmechanik der Atomspektren [Group Theory and its Application to the Quantum Mechanics of Atomic Spectra], Wigner demonstrated the profitability of group theory and the notions of symmetry properties and invariance in particular as a means to explain the properties of atom and atomic nuclei. It is interesting to note that connection of symmetry and the invariance of some physical quantity plays an important role in the discovery of the ancestor of the electric motor by Ányos Jedlik in 1828. In the written series of Jedlik's demonstration experiments the Amper experiment of the interaction between two symmetric straight wires carrying direct electric current (translation, conservation of momentum) followed by the electric motor containing two electric magnet (rotation, conservation of angular momentum: Jedlik built a motor model in wich both part of the motor could rotate).

\section{Eugene Wigner one of the key persons of the atomic bomb}

The USA was very grateful to Wigner. Citation to accompany the award of the medal for merit january 12, 1946 to $d r$. Eugene Wigner:

"DR. EUGENE PAUL WIGNER for exceptionally meritorious conduct in the performance of outstanding service to the War Department, in accomplishments involving great responsibility and scientific distinction in connection with the development of the greatest military weapon of all time, the atomic bomb.

As physical researcher in the Metallurgical Laboratory at Chicago on the MET project for the Manhattan Engineer District, Army Service Forces, he was one of those primarily responsible for the essential theoretical developments which led to 
the construction of the chain-reacting piles at Hanford Engineer Works. A theoretical physicist of international distinction, Dr. Wigner's sound scientific judgment, his initiative and resourcefulness, and his unselfish and unswerving devotion to duty have contributed significantly to the success of the Atomic Bomb project."

Signed: Harry Truman

Remember: John von Neumann Wigner's school mate and longlife friend received the Medal of Freedom in 1956 from Eisenhower "for exceptional meritorious service in promoting the scientific progress of his coutry's armament program."

\section{Jenő Wigner the grateful pupil}

The thoughts of Wigner as related in a commemorative article published in 1973 and a speech delivered to Hungarian students in 1988 convey the profundity of those sentiments which he expressed on numerous occasions in connection with the decisive influence of his teachers and the Budapest Lutheran Gymnasium.

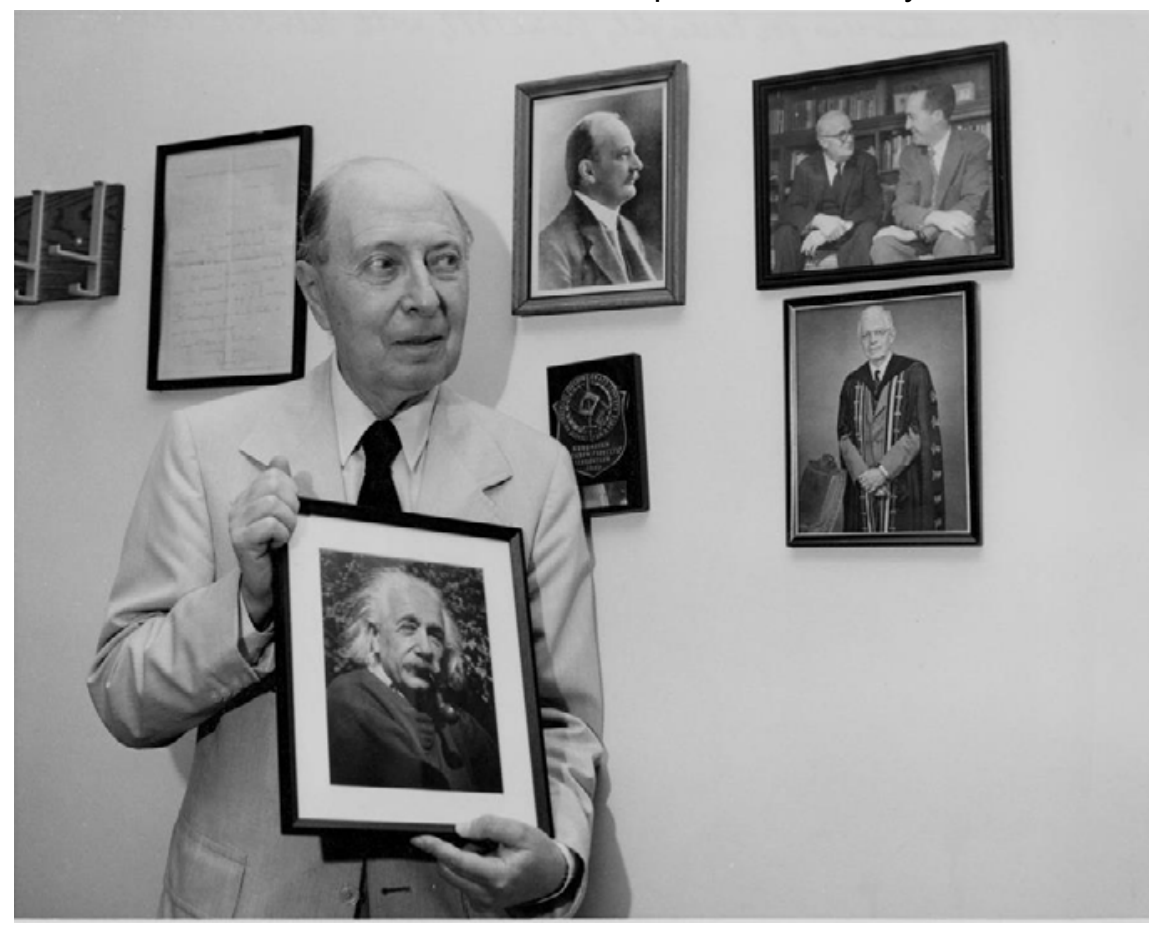

Wigner in his studyroom in Princeton

"The portrait of László Rátz ... is in my workroom at Princeton University. He taught us not just at school. Not only did he recognize the extraordinary talent of János Neumann in its embryonic stage, but he gave him (gratis) private lessons in mathematics. László Rátz also supplied me with highly useful books from which I learned not only mathematics but got acquainted with the miraculous world of inferences... I remember almost all of my teachers with joy. Imre Oppel acquainted us not only with the rudiments of geometry, he was our physical educator as well. Oppel was one of our youngest teachers and I stayed in touch with him up to his 
death [indeed, Wigner even arranged to have the royalties from Hungarian language editions of his works sent to Oppel during the latter's penurious retirement with the help of the Hungarian interpretator of his books, the famous nuclear physicist and great man Géza Györgyi]. Jenö Gretzmacher primarily taught German language and literature, focusing on Wilhelm Tell. Szolár was our Latin teacher and sometimes I still enjoy reading those materials which he had introduced. Kubacska taught natural science and for a very long period of time I was not sure whether botany or mathematical physics was my favorite subject. ... It should be noted ... how helpful it was for our teachers ... that they were not isolated from the university. My teachers knew their university colleagues, and sometimes on Saturday afternoons they got together in a coffeehouse. Later on a few times, they invited me there (to those afternoon discussions). Such occasions, sorry to say, do not exist in America, at least not at Princeton."

("Visszaemlékezéseim az iskolára" [My recollections of the school]. Fizikai Szemle no. 10, 1973, pp. 297-298. Cited and translated in Wagner, Francis S. Eugene P. Wigner an architect of the Atomic Age. 1981, Toronto, Rákóczi Foundation. p. 11).

The last words of Wigners' reminincense:

"Shall I now repeat myself saying that I keep thinking of my secondary school with profound gratitude and deep love, of the school where I have learned so much? That I often remember my days at school with overwhelming longing? That it would take hours to tell you all I remember about my school? I believe that anyone filled with similar emotions will know that and anything my words can only imply." 
